\title{
An Argumentative Approach to "Framing" Framing, Deliberation and Action in an Environmental Conflict*
}

Received: 10/09/2019 | Reviewed: 31/03/2020 | Accepted: 01/04/2020

DOI: 10.17230/co-herencia.17.32.5

\author{
Isabela Fairclough** \\ ifairclough@uclan.ac.uk \\ Irina Diana Mădroane*** \\ irina.madroane@e-uvt.ro
}

\begin{abstract}
This paper proposes a new theorization of the concept of "framing", in which argumentation has a central role. When decision-making is involved, to frame an issue is to offer the audience a salient and thus potentially overriding premise in a deliberative process that can ground decision and action. The analysis focuses on the Roşia Montană case, a conflict over policy that developed over the years into an environmental social movement and, in September 2013, culminated in the most significant public protests in Romania since the 1989 Revolution. Starting from Entman's understanding of framing as "selection and salience", several framing strategies are identified and discussed, illustrating three main mechanisms. The way in which "selection and salience" operates via a range of argument schemes in a deliberative, decision-making process, in order to produce framing effects (including, possibly, collective mobilization) is illustrated with examples from the 2013 campaign and protests (slogans, websites, blogs and newspaper articles).
\end{abstract}

\section{Keywords:}

Argument scheme, categorization, collective action, decision, deliberation, explanation, frame, framing, metaphor, narrative, persuasive definition, Roşia Montană.

\section{Aproximación argumentativa al "framing". Enmarcado, deliberación y acción en un conflicto ambiental}

Resumen El presente artículo propone una nueva teorización del concepto de framing o marco, en el cual la argumentación cumple un papel fundamental.
"This is a revised and updated version of our paper for the ISSA 2014 conference, published in the Proceedings of the $8^{\text {th }}$ (ISSA) Conference of the International Society for the Study of Argumentation, as Fairclough \& Mădroane (2014), with the title "An argumentative approach to policy 'framing'. Competing 'frames' and policy conflict in the Roşia Montană case". 
Cuando hablamos de tomar decisiones, enmarcar un asunto implica ofrecer a la audiencia una premisa destacada $y$, por ende, posiblemente primordial en un proceso deliberativo que permite fundamentar tanto la decisión como la acción. El análisis se centra en el caso de Roşia Montană, una controversia sobre políticas públicas que, con el correr de los años, se transformó en un movimiento socioambiental y que, en el mes de septiembre de 2013, culminó en las protestas más importantes que se vivieron en Rumania desde la Revolución de 1989. Partiendo del concepto de framing que Entman entiende como "selección y énfasis", se identifican y comentan varias estrategias de enmarcado que ilustran tres mecanismos principales. La manera en que operan la "selección y el énfasis" a través de una serie de esquemas de argumentos dentro de un proceso de decisión deliberativo para producir efectos de enmarcado (incluida, posiblemente, la movilización colectiva) se ilustra con ejemplos de la campaña y las protestas de 2013 (eslóganes, sitios web, blogs y notas periodísticas).

\section{Palabras clave:}

Esquema de argumento, categorización, acción colectiva, decisión, deliberación, explicación, marco, framing, metáfora, narración, definición persuasiva, Roşia Montană.

\author{
** School of Huma- \\ nities, Language \\ and Global Studies, \\ University of Central \\ Lancashire, Preston \\ PR1 2HE United \\ Kingdom. ORCID: \\ 0000-0001-6718-2636 \\ *** Department of Mo- \\ dern Languages and \\ Literatures, West Uni- \\ versity of Timișoara, \\ Romania. ORCID: \\ 0000-0002-7978-0374
}

This article develops an approach to framing theory from the perspective of argumentation theory (Fairclough \& Fairclough, 2012). It puts forward a view of "framing" as a process of offering an audience salient and potentially overriding premises that they are expected to use in deliberation leading to decision and action (Fairclough, 2016). We suggest three basic mechanisms, and then illustrate six framing strategies with examples taken from the public protests against the proposed cyanide-based gold mining project at Roșia Montană (Romania). This mining project, whose beginnings go back more than 20 years, though no gold has been extracted to this day, was to set the Romanian government and a multinational company against a majority of the population, creating the most significant social movement in Romanian post-1989 history. In September 2013, the conflict culminated in the most intense public protests since the fall of communism. The outcome was the rejection by the Romanian Parliament of a draft law that would have given the green light to the largest open-cast, cyanide-based gold mining operations in Europe. While our primary aim here is theoretical and methodological, we also want to show how the strategies we describe were used by the protesters and, more generally, how our 
approach can contribute to an understanding of decision-making and (collective) action.

\section{Roşia Montană: A Brief Overview}

Roşia Montană is a commune of 16 villages, situated in the Western Carpathians (the Apuseni Mountains), in a picturesque region known as Romania's "Golden Quadrilateral”. It has a recorded history of over 2000 years and has been a traditional gold-mining area since Roman times. The area is rural and underdeveloped, with few employment possibilities, and in need of a strategy for sustainable development (Plăiaş, 2012). The controversial mining project advanced by the Canadian corporation Gabriel Resources Ltd. in partnership with the Romanian state (renamed Roşia Montană Gold Corporation in 2000, henceforth RMGC) claimed to provide such a strategy, by "bring[ing] one of the world's largest undeveloped gold projects to production" (Gabriel Resources, 2015, p. 12). The project required large-scale cyanide-leaching procedures to extract an estimated 314 tons of gold and 1480 tons of silver from 4 open-cast pits over a 16-year period. While the economic benefits to the Romanian state were invariably presented by the corporation as significant, Romania's equity stake in the company was only $19,31 \%$ (through Minvest Roșia Montană S. A.), the other 80,69 \% being owned by the Canadian company Gabriel Resources (according to 2015 data provided by the company).

Mădroane (2014) investigated the company's argument in favour of the project in terms of the framework for reconstructing, analyzing and evaluating practical arguments developed by Fairclough \& Fairclough (2012). According to this framework, a practical proposal is advanced on the basis of premises specifying the intended goals of action, the circumstances of action and a means-goal relation, and should be evaluated via an argument from consequence. The circumstances of action include natural, social and institutional facts that enable or constrain the action, and some of these facts constitute the "problem" to be resolved by means of the proposed action (as "solution"). For an approach to framing, rhetoric and communication that incorporates the deliberation scheme from 
Fairclough and Fairclough (2012), applying it to migration discourse, see Cârlan and Ciocea $(2014,2018)$ and, more generally, Beciu, Ciocea, Mădroane, \& Cârlan (2018).

RMGC's overall problem-solution argument, summed up on the company's website, includes a description of the area's serious problems (in four areas - economy, environment, patrimony, community) and the absence of viable alternatives for sustainable development. Joint economic benefits (including for the region and the Romanian state), as intended goals of action, are prominent on the website, and a number of commitments (as constraints on action) are emphasized. The company claims to be committed to norms of environmental and archaeological protection and rehabilitation, to respecting the local population's right to property and right to work, and to sustainable development (Mădroane, 2014). Aiming to address all of the area's problems, the company claims to hold the key to transforming an "impoverished community with no real alternative" in accordance with a "vision" of "prosperity, growth, clean environment", offering a "long term future for Roșia Montană" (Gabriel Resources, 2015, p. 11). What has always lain at the centre of RMGC's campaign to win over public opinion is the packaging of the project as the much-awaited solution to the economic and social plight of the region, as well as a welcome contribution to Romania's economic growth (see also Chiper's analysis of the RMGC project, 2012).

From the start, the gold mining project at Roșia Montană was highly controversial, due to its potential infringement of existing legislation (mining laws, property rights, national heritage protection, urbanism plans), the confidentiality of the terms of the original 1999 concession licence, the intense pressure exerted by RMGC via aggressive lobbying and advertising campaigns, as well as the superficial nature of the public consultation process and the suspicion of widespread institutional corruption. Expert analyses of the project pointed out numerous potentially unacceptable risks and impacts: the permanent destruction of the local environment (mountains and forests), together with long-term environmental and public health risks posed by the massive quantity of cyanide (12 000 tons of cyanide were going to be used and 13 million tons of mining waste produced each year, eventually leaving behind a 
lake containing 215 million cubic metres of cyanide-contaminated water). In addition, the irretrievable loss of ancient cultural heritage (Roman mine galleries); the destruction and displacement of local communities; the comparatively small economic benefits to the Romanian state and to the local community. The alleged benefits were dismissed in scientific reports and studies published by reputable national and international research institutions, including the Romanian Academy, the Bucharest Academy of Economic Studies, the Union of Romanian Architects.

In 2000, a group of villagers from the areas earmarked for destruction created Alburnus Maior, a non-governmental organization (led by Eugen David) named after the ancient Roman settlement on which Roșia Montană stands, and (two years later) launched a campaign called "Save Roșia Montană", aimed at stopping the project. This campaign soon became the main pillar of an increasingly strong protest movement, catalyzing other NGOs and concerned citizens, and benefitting from the help of experienced environmentalist campaigners, most notably Stephanie Roth, who had worked for The Ecologist and was familiar with similar mining projects on other continents (Goțiu, 2013, pp. 343-353). Thanks to her, as early as 2002, the World Bank withdrew its financial support for the project. Alburnus Maior also managed to cause the suspension, in 2007, of the Environmental Impact Assessment procedure, which would have been a crucial step for RMGC towards obtaining the environmental permit.

The attempt to get the project started was resumed in 2010, in the general context of economic recession, with the support of a range of politicians, including President Traian Băsescu, and Prime Ministers Călin Popescu Tăriceanu and Victor Ponta. On August 27, 2013, the Romanian government sent a draft law to Parliament, allowing RMGC to bypass all the environmental and heritage regulations that had prevented it from going ahead and removing all remaining legal obstacles. This perceived act of government corruption sparked off strong public protests in many Romanian cities, lasting over 6 weeks: at the peak of these protests, 20000 25000 people were demonstrating daily on the streets of Bucharest. Overwhelmed by the population's sustained collective outrage, 
Parliament was forced to reject the special draft law. (It was rejected by the Senate on 19 November 2013, and by the Chamber of Deputies on 3 June 2014). Meanwhile, the stock price of Gabriel Resources Ltd. was sent plummeting.

Although, following the extraordinary mobilization of Romanian civil society in 2013, the project was abandoned, the Romanian Government granted, in 2019, a 5-year extension to RMGC's mining licence (whose 20-year term had expired). Meanwhile, in 2015, at the International Centre for Settlement of Investment Disputes, Gabriel Resources registered an arbitration claim against the Romanian state for the mining concession at Roșia Montană, claiming 4,4 billion US dollars in damages, for the loss of expected profits. The first case hearing took place in December 2019 in Washington D. C.; at the moment of writing, a second hearing is scheduled for September 2020, in Paris.

There is already an extensive literature on this topic. Egresi (2011) analyzes the emergence of two main discourses on the environment at Roșia Montană, with the mining industry and environmental groups upholding the goal of sustainability from two opposite perspectives. Chiper (2012) studies the governance and resistance strategies developed in discourse by multiple actors (the corporation, politicians, publics). Goțiu (2013) investigates the history of the project and of the protest movement, critically interrogating the actions of stakeholders and politicians, including their legality, while providing a wealth of factual information on the media coverage and the emergence of a "culture of resistance" within the movement after 2010 (Goțiu 2013, p. 376 ff). Vesalon and Crețan (2013) examine the production of alternative knowledge ("civic expertise"), e. g. the movement's own construction of environmental risk, and its contribution to public debate. Similarly, Velicu (2012, 2014, 2015) focuses on the emergence of alternative discourses of resistance from "moral economy" and "aesthetic revolution" perspectives. Recently, Soare and Tufiș (2020) have looked into the development of activism practices and networks at Roșia Montană, before and after Romania's EU accession in 2007, and into the diversification of the actors engaged in policy decision-making. 
These studies deal with the formation and dynamics of discourses, counter-discourses and arguments on the Roșia Montană case over a span of almost twenty years. The 2013 protests we are referring to here were a peak in an otherwise lengthy and convoluted development, involving both the mainstreaming of the corporation's project (with political and media support) and the gradual emergence of counter-arguments, objections, dialogue among multiple parties, and strong polarization and conflict.

\section{Practical Reasoning in Deliberative Activity Types}

Practical argumentation is argumentation about what ought to be done (or not), as opposed to theoretical argumentation about what is (or is not) the case (Walton, 2006, 2007; Walton, Reed, \& Macagno, 2008). Van Eemeren (2010, pp. 142-143) distinguishes among genres, activity types and concrete speech events. A particular policy debate (e. g. on the Roșia Montană mining project) instantiates the more abstract category of policy debate as activity type, which in turn instantiates the abstract genre of deliberation. Deliberation is a genre common to many activity types; its intended outcome is a normative-practical conclusion that can ground decision and action (Fairclough \& Fairclough, 2011, 2012, 2013). On the view proposed here (and in Fairclough 2019a), deliberation is an argumentative genre which combines two main argument schemes: argumentation about what course of action ought to be adopted (in light of desirable goals) and argumentation on what course of action ought to be avoided (in light of undesirable potential consequences).

In order to resolve problems, deliberating agents put forward (alternative) proposals for action, conjecturing that these might help them achieve their goals. For decision-making to be rational, agents should subject these proposals to criticism in light of their potential consequences (Miller, 1994, 2006). The decision to adopt a particular proposal A will be reasonable if the hypothesis that $\mathrm{A}$ is the right course of action has been subjected to critical testing in light of all the knowledge available and has survived criticism (Fairclough, 2019a, 2019b). The proposal will withstand criticism, and thus emerge as a potentially reasonable course of action, if no 
unacceptable (intended or unintended) consequence has come to light as a possible objection to it. "Consequences" include risks and impacts, and these may be assessed as acceptable or not. Impacts may include situations where a proposal would clash with, or go against a moral or institutional principle, rule or norm. It is not uncommon for such impacts to be evaluated as unacceptable (because the obligations and rights derived from laws, rules and norms are often seen as nonoverridable). Even if the intended effects (goals) are desirable and therefore withstand criticism, the unintended consequences, to the extent they can be foreseen, may be such that the action had better not be performed, even if the intended desirable effect can be achieved by doing A. If this is the case, then a "decisive objection" to the proposal has been exposed, and the hypothesis that the agent ought to do A has been falsified (or rebutted). An argument from negative consequence, when a negative consequence has emerged as unacceptable to the deliberators, will rebut the proposal.

A succinct way of representing argumentation in deliberative activity types is as follows (Figure 1), where the conclusion of the practical argument ${ }^{2}$ from goals, values and circumstances is subjected to critical testing in light of its potential consequences. Deliberation, on this view (Fairclough, 2019a, 2019b), involves two main (obligatory) argument schemes (argumentation from goals, and argumentation from negative consequence) and any number of non-essential argument schemes that may support the premises

1 The term "decisive objection" is used here instead of "critical objection", used in the 2014 version of this paper, to accord with recent publications (Fairclough, 2018, 2019a, 2019b, 2019c). Against any proposal, critics may bring various "critical objections". In a deliberative context, some will be assessed "decisive objections" (objections indicating the proposal should not go ahead), while some as mere "counter-considerations" (objections that do not rebut the proposal). For example, if an industrial development risks contaminating local water sources, decision-makers might find this risk a decisive objection; the fact that the same development will to some extent ruin the beauty of the landscape might be considered a mere counter-consideration, but not a decisive objection. Different parties to a debate might assess these objections differently, and what is a mere counter-consideration for one party may be a much stronger, decisive objection (a rebuttal) for another. The distinction between "decisive objections" and "counter-considerations" is explored in other publications (Fairclough, 2019a, 2019b, 2019c).

2 In the literature, the argument from goals is called a "practical argument" (Walton et al., 2008), while the argument from consequence is called a "pragmatic argument" (Van Eemeren \& Grootendorst, 2004). For the sake of simplicity and to avoid confusion, this distinction will not be preserved here. 
or the conclusions of these arguments (e. g. argument from positive consequence, ${ }^{3}$ from expert opinion, etc.). This is of course, a normative framework, indicating how deliberation ought to proceed if decisionmaking is to be rational. Whether an individual is deliberating with oneself or with others, no proposal ought to be accepted unless it has been subjected to the most stringent criticism, i. e. unless all the critical questions pertaining to the argument schemes involved have been asked and answered in a satisfactory manner, and no decisive objections have emerged. In practice, however, the relevant questions may not be asked, or -if asked- they may be answered in ways that show insufficient or erroneous understanding of the possible consequences, of the means at the agents' disposal, or of the situation they are in. Typically, the decisive objections raised by one party will be downplayed by the other party, who might claim that the alleged risks will not in fact occur, or will be suitably controlled if they do, or that the impacts can be suitably mitigated, thus allowing the proposal to proceed. Since proposals are about the future, and their potentially unacceptable consequences have not materialized at the time when a proposal is made (and some may indeed not materialize), what follows is often a war of attrition in which a proposal's opponents cannot conclusively refute it in light of what they see as decisive objections, because its supporters claim that those objections are not in fact decisive, or should be overridden by other more important concerns (see Fairclough 2019a on a similar conflict on shale gas exploration in the UK). ${ }^{4}$ In public debates on controversial issues, the critical questions attached to the argument schemes involved in deliberation are asked and answered continuously by the actors directly affected by a proposal, by decisionmakers, but also by the general public, the experts and the media.

3 Goals can, of course, be viewed as intended positive consequences. However, argumentation from goals is a different argument scheme from argumentation from positive consequence. Agents start with goals, and then put forward proposals in light of these goals. Subsequently, those proposals might also be defended on the grounds of their additional positive consequences, that were not intended (as goals) at the moment of putting forward the proposals.

4 For the controversy over shale gas in Europe and the US, see also Lewiński (2016) and Aakhus \& Lewiński (2017). 


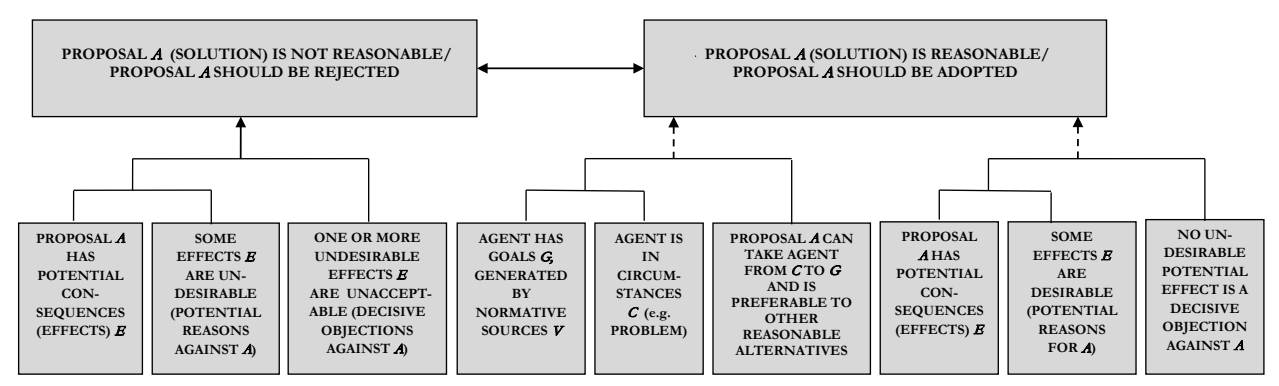

Figure 1. The deliberation scheme (Fairclough, 2019a, 2019b): a proposal is tentatively supported by an argument from goals (and, optionally, from positive consequence) - centre and right-hand side - but will be conclusively rebutted by an argument from negative consequence - left-hand side - if those consequences constitute decisive objections.

As Figure 1 shows, we reason from an assessment of the circumstances of action, from the goals and values whose realization we are pursuing, and from means-goal relations we are aware of, as well as from premises that refer to the potential consequences of our proposed action. If the potential consequences seem, on balance, to be unacceptable, then the proposal is unreasonable and ought to be abandoned. If the foreseeable effects are not unacceptable, then the action may tentatively proceed, subject to future rebuttal, should decisive objections come to light at a later date. In actual deliberative practice, arguers often try to strengthen the conclusion by adducing arguments in favour of a proposal in the form of other positive consequences (in addition to the intended goals). Logically, however, it is never reasonable to conclude that a proposal should go ahead only on the strength of the positive consequences it may realize, nor on the strength of its capacity to achieve desirable goals, unless it is also true that no decisive objections have emerged during the deliberative process, i. e. unless the proposal is not likely to have unacceptable consequences (impacts, risks) for those who will be affected by it.

A decisive objection against a proposal (e. g. an unacceptable potential cost) is one that cannot be overridden by other reasons in favour (e. g. by any potential benefit). The institutional facts (obligations, rights, commitments) of the legal, political, moral domain (what Searle, 2010 calls deontic, desire-independent reasons) 
are, in principle (though not always in practice), non-overridable. For example, an agent might reasonably come to the conclusion that Proposal A ought to be abandoned because it is against the law, regardless of a substantial range of benefits that might have originally tempted him to go ahead with it (Fairclough, 2015, 2016, 2019a, 2019b, 2019c).

\section{Framing as Selection and Salience: Three Mechanisms}

According to Entman, writing in 1993, framing theory is a good example of a "fractured paradigm", with a highly "scattered conceptualization" at its core. While everybody in the social sciences talks about framing, there is no clear understanding of what frames are and how they influence public opinion (Entman, 1993, p. 51). Many often-cited definitions in the literature are vague and unhelpful, e. g. those of frames as "organizing principles that are socially shared and persistent over time" (Reese, 2001, p. 11), or as "principles of selection, emphasis and presentation composed of little tacit theories about what exists, what happens, and what matters" (Gitlin, 1980, p. 6). The same type of criticism still occurs twenty years later (see D'Angelo \& Kuypers, 2010), with Nisbet noting the persistent loose usage of the term "frame" and every researcher's tendency to "reinvent the wheel" by identifying their own (often highly idiosyncratic) set of frames, without thereby producing a clear operationalization of the concept that might be used across different sets of data (Nisbet, 2010, pp. 45-46).

There is at least one clear definition of "frames", in the cognitive semantics literature, though this is not the definition that most framing theorists, working in political communication and media studies, seem to start from. This is Fillmore's $(1985,2006)$ definition of "frames", as developed in Frame Semantics and the FrameNet project (International Computer Science Institute, n. d.) -a new dictionary concept, in which words are defined in relation to world knowledge. On this understanding, frames are structures or systems of inter-related concepts, "information packets", such that in order to understand any one concept it is necessary to understand the entire 
system (frame). To understand what "risk" is, for example, one needs to understand the entire RISK frame, involving agents, situations, actions, intended gains or benefits, potential harm and victims, an element of chance/probability, and so on (Fillmore \& Atkins, 1992). The RISK frame is evoked (and activated) by a wide range of words, e. g. "This proposal risks damaging the environment", but also by "This proposal might damage the environment".

A substantial part of framing theory research seems to be underlain by a different understanding of what frames are, which is primarily an understanding of the framing process, rather than of frames as Fillmorian systems of concepts. On this view, a "major premise of framing theory is that an issue can be viewed from a variety of perspectives", and "framing refers to the process by which people develop a particular conceptualization of an issue" (Chong $\&$ Druckman, 2007, p. 104). It is this selective angle or perspective that is often responsible for the phenomenon of "framing effects", where "(often small) changes in the presentation of an issue or an event produce (sometimes large) changes of opinion" (Chong \& Druckman, 2007, p. 104). The Roșia Montană conflict has, for example, been viewed from an economic, environmental, moral, legal, political, public health perspective. These perspectives might support radically different courses of action: from an environmental perspective, it was argued that the proposal ought to be abandoned (in light of the decisive objections that were raised against it), while from an economic perspective, to the extent that it would bring benefits to the local area, it was argued that it ought to go ahead. The same perspective can be used to support opposite standpoints: from an economic perspective, the proposal should go ahead because it will bring jobs and national revenue; from the same perspective, it should not, because the economic benefits will be minimal, and far greater benefits could result from local tourism, which the proposal would compromise. 
The most often cited definition of framing is Entman's (1993) view of framing as selection and salience:

Framing essentially involves selection and salience. To frame is to select some aspects of a perceived reality and make them more salient in a communicating text, in such a way as to promote a particular problem definition, causal interpretation, moral evaluation, and/or treatment recommendation for the item described. Typically frames diagnose, evaluate, and prescribe [...] (1993, p. 52).

Entman's selection-and-salience definition above is a definition of "framing", not "frames". Framing is seen to involve inclusion, exclusion, selective emphasis, for various aims. Agents may, for example, choose to emphasize the benefits of a course of action and correspondingly de-emphasize the costs, in order to sway an audience towards accepting their proposal. Although Entman does not develop his view in relation to a theory of argument, his definition is compatible with an approach from argumentation theory. If the framing process aims to define and diagnose problems, as well as suggest solutions, then it is a form of practical, deliberative reasoning, attempting to direct the audience towards a particular conclusion, a particular line of action, seen as a solution to the identified problem.

In the literature on social movements and mobilization, framing processes consist in "defining what is going on in a situation in order to encourage protest", or "forging collective action frames" (Noakes \& Johnston, 2005, p. 2). Benford and Snow (2000) define collective action frames as an interactive process of diagnosing problems, offering solutions and motivating social agents to take action, while Gamson $(1995,2013)$ emphasizes the identification of "injustice" as part of diagnosing a problem, and a crucial element in motivating the public to become engaged. In addition to the identification of a problem and a possible solution (an approach similar to Entman's), social movement theorists include a "motivational" component: framing should attempt "to give people a reason to join collective action" (Noakes \& Johnstone, 2005, p. 6). A form of subjective engagement is therefore needed: in order to motivate people to move to action, frames must ring true or "resonate" with people's beliefs and values (Noakes \& Johnstone, 2005, p. 2). According to Gamson (1995, p. 91), a crucial role in mobilization is played by emphasizing 
the "injustice" that has been committed (what he calls an "injustice frame"), so as to arouse emotions of "righteous anger" and moral indignation (see also Mădroane, 2016)..$^{5}$

Deliberation involves arguers/agents in a situation of incomplete knowledge (uncertainty and risk), putting forward and evaluating alternative proposals for action, amongst which they will choose and decide. They have goals and values, and are acting in a context of facts, some of which enable or constrain action -for example there are laws, rules, norms that may constrain or facilitate action, and certain lines of action are (physically or practically) possible or impossible. The agents' proposed action has potentially negative consequences, some of which might be assessed as decisive objections against it. Within this process, various reasons may be emphasized in principle as being the most relevant and important, i. e. the ones that should decide which course of action is adopted. For example, it can be argued that a policy proposal should be adopted because it will create jobs (positive consequence), or it can be argued that it should not be adopted because of its potential negative impact on the environment (negative consequence). In a process of weighing reasons, the audience may come to see either the benefits (jobs) or the costs (pollution) as more significant, even overriding, reasons and the conclusion (and decision) they will reach may shift accordingly. Similarly, values or other "normative sources" (Fairclough \& Fairclough, 2012, p. 43) may be made more salient. For example, it may be argued that a controversial industrial project ought to be rejected in light of existing legislation (creating obligations to abide by the law), moral-political values (justice) and the local population's rights. The campaign against such a project could be 'framed' in terms of the law, of justice and of rights.

Briefly, making one premise of the deliberation scheme more salient, while correspondingly de-emphasizing others, is expected to result in a shift in the decision for action that the audience will

5 Mădroane (2016) has studied media advocacy campaigns that seek to mobilize publics to sign petitions or support a cause and is currently developing an analytical framework based on the literature on practical argumentation and rhetoric, which integrates elements from the analysis of motivational framing and mobilization in social movements (Mădroane, 2018, 2019). 
arrive at, given that the salient element is expected to override nonsalient elements in the process of "weighing" reasons. It does not follow, of course, that the audience will be actually influenced in the intended way, nor that they will automatically ground their conclusions (and decisions) in the premises made salient through framing. In real-world contexts, framing effects are weakened by the public's exposure to alternative arguments, by their ability to come to their own conclusion, as well as by their pre-existing beliefs and values (Sniderman \& Theriault, 2005; Chong \& Druckman, 2007). In situations of social protest, collective action frames may be partly responsible for producing the desired effects (change of beliefs, mobilization to act) if they "resonate" with the target public by becoming "attuned" to a common "stock" of cultural symbols, beliefs, and values, but also to "the social and political context in which the movement is operating" (Noakes \& Johnston, 2005, p. 24), which social movement entrepreneurs aim to address in the ways they diagnose a problem or offer a solution.

We suggest that, in framing an issue in a particular way, i. e. in making particular aspects of it selectively more salient, a communication source (the media or political elites) can be viewed as supplying those particular premises that may lead the audience towards a particular conclusion. The communication source can talk about an issue by means of any complex speech act -argument, narrative, definition, description, explanation; the audience however are expected to use these as sources for premises in the construction of arguments leading to their own decision (and potentially, action). From the audience's perspective, the aspects that are being selected and made salient are the premises of a deliberative process, aimed at arriving at some decision about what to believe or do. It is these premises (values, goals, consequences, circumstances, etc.) that can be made selectively more salient and thus possibly influence the deliberative process. We agree with Nelson et al. that "the emphasis placed on these alternative facets of the issue elevates the perceived relevance or importance of these considerations compared to others", in other words may make them "seem relatively more important and especially relevant" to the decision (Nelson, Clawson, \& Oxley, 1997, p. 569), or potentially overriding. 
The gist of the argumentative approach to framing being proposed here is this: to frame an issue is to offer the audience a salient and thus potentially overriding premise in a deliberative process that can ground decision (about what to believe and what to do) and action. Any of the premises of the argument schemes involved in deliberation can be made selectively more salient in an attempt to direct the audience towards a particular, preferred practical conclusion (or 'solution'): negative or positive consequences, goals, values, available means, 'problems' (but also 'expert opinion', if the proposal is also independently supported by an argument from authority). We suggest this is the first and most basic framing mechanism: the selective salience given to a premise in one of the main argument schemes that directly support the proposal or its opposite. This could involve making more salient (and potentially overriding) the alleged benefits (jobs and revenue) of a policy proposal versus the potential costs (environmental destruction, risk to public health), to steer the audience towards the conclusion that it ought to be adopted or rejected, respectively.

Salience may be then further increased by a 'seeing as' mechanism: there is therefore often a second mechanism at work, involving the use of metaphors, analogies, definitions, categorization and value-laden language to (re-)define or (re-)categorize facts in rhetorically convenient ways. If the negative impacts of a proposal are not merely being stated, and (implicitly or explicitly) said to be overriding in relation to the positive ones, but are also related to another domain of experience, then salience may be achieved through the power of the unexpected and rhetorically persuasive metaphor, analogy, categorization or definition. We see these metaphors and definitions as supporting the premises of the basic arguments used in deliberation -from goals or from consequence. Figure 2 suggests how a metaphor or definition, used to re-express the unacceptable consequences of a proposal in a more rhetorically persuasive (and therefore also more salient) way fits into the basic deliberation scheme. The salient premise contained in subordinate arguments from analogy, definition or classification supports the premise expressing the 'decisive objection' against the proposal and indirectly the conclusion that the proposal ought to be abandoned. 


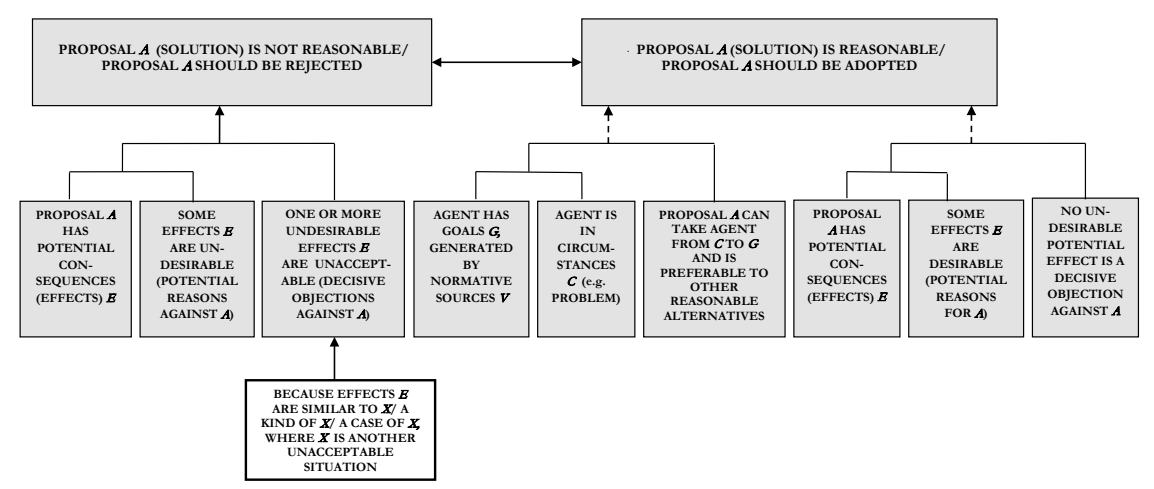

Figure 2. The deliberation scheme: making salient a premise in a secondary argument scheme (e.g. analogy) that supports the existence of decisive objections against the proposal.

Definitions, analogies or metaphors occur in argument schemes embedded under the main arguments of the deliberation scheme. Premises of the form $a$ is $a$ kind of $b$, or $a$ is similar to $b$, can provide justification (support) for the (premises of the) arguments from goals or consequence. The same effect is obtained by casting the argument within a particular "frame", i. e. by categorization. In all these cases of "framing", logical inferences (entailments ${ }^{6}$ ) drawn from one domain are used to reason about another domain. This mechanism is amply illustrated by Lakoff and Johnson's (1980) theory of metaphor (see also Lakoff, 1993), but is also discussed by various theorists of policy framing, though not necessarily in the same terms (e. g. Schön's 1993 analysis of "generative metaphor"). The choice of a frame, definition or metaphor (in argument schemes from classification, definition or analogy) generates a set of inferences which are transferred to the understanding of a new situation, leading to particular conclusions.

In the campaign we are studying here, the actions of the government and the corporation were often labelled as theft or robbery, or as a criminal and corrupt activity. Through its entailments, the crime frame can only support the argument against the proposal: if what is going on amounts to crime/robbery/theft, then, since these are illegal and wrong, the proposal should be rejected. Going against

6 Entailment is a semantic inference, a relation of logical implication between propositions: if it is true that something is an act of theft, then it is also true that it is wrong/illegal. 
the law or against moral norms is, in other words, an unacceptable consequence of the proposal, a decisive objection against it. These frames and their entailments were bound to resonate with widespread views circulated in the public space in post-communist Romania about the corruption of politicians, their incompetence and their attempts to gain personal benefits from the privatization of state industries, which had nurtured a sense of injustice (Mădroane, 2016, 2018). On the other hand, it was argued that the effects of the project would be beneficial, because they would amount to actually saving the Roșia Montană area from poverty and environmental catastrophe. If a proposed action amounts to salvation from harm or danger, then the action is recommended. The spin or bias that the choice of semantic frames, persuasive definitions or metaphors can introduce into the premises of an argument will be reflected, via their entailments, in the particular conclusion that can be reached on the basis of those premises.

Yet another, third mechanism involves drawing on nonargumentative macro speech acts (narrative, explanation) for (additional) support of the preferred conclusion. The moral dimension of narratives, for example, gives them the power to fuel moral indignation (Gamson, 1995, 2013) and mobilize publics to act (Mădroane, 2016; see also Mădroane 2018, 2019; Velicu 2012). Explanations assign causes to events but also, potentially, responsibility and blame, and can therefore mobilize for the same moral reasons. We will discuss examples of all these three mechanisms in the next section, and illustrate them with examples of 6 basic framing strategies (without claiming this is an exhaustive list). Our analysis is exploratory; as such, it could be further developed into a case study of this protest movement and its representation in the media, but this is beyond our limited aims here.

\section{Six Strategies. How Does Framing Work?}

In order to test and illustrate how the analytical framework described in section 2, as well as the three main mechanisms outlined in section 3 can throw light on framing processes, including framing effects, we will discuss a few examples taken from the campaigns in 
favour and against the mining project (leaflets, placards, campaign slogans, blogs, website information) and from the media coverage of the protests. These examples illustrate how Entman's selection and salience mechanism functions in several distinct ways (we discuss six of these below as 6 different framing 'strategies'):

1. First and foremost, the simplest framing mechanism involves the selective salience given to one or another of the basic premises (goals, values, consequences, etc.) of a practical reasoning, deliberative process. As we have already said, depending on whether the positive or the negative consequences are emphasized, an audience is invited to conclude in favour or against a proposal. The emphasis given to alternative values functions in the same way: a focus on economic growth as primary concern might indicate that an industrial development based on fossil fuels should go ahead (though the proposal can be criticized for its negative effects on the environment, which might be taken as a decisive objection against it). An alternative focus on a concern for the future safety of mankind and care for the environment might indicate that giving up fossil fuels is the right course of action (though this proposal too might be criticized in terms of its unrealistic economic costs, uncertain reliability and the undesirable lifestyle changes it would require, which again might be taken to be decisive objections against it). Other alternatives to fossil fuels (the development of renewable energy sources) may be then tested in turn, and their various benefits and costs, as well as the overriding concerns motivating them, might be made selectively more salient.?

7 These two examples (involving positive and negative consequences and competing values) show how the deliberation scheme can be used to decide both whether to adopt a course of action or not ( $\mathrm{A}$ vs non- $\mathrm{A})$, but also to decide among alternative courses of action (A, or B, or C), if several are available. Both "doing A" and "not doing A" should be tested in turn, in light of their goals and consequences; similarly, "doing B" and "not doing B". This is to say that the box at the top-right of Figure 1 should be filled alternatively by "Doing A is the right course of action" and "Not doing A is the right course of action". Similarly for alternatives B and non-B, etc. 
But framing also clearly works by selection and salience in many other ways, for example by:

2. Selecting and making salient a particular "frame", in Fillmore's sense. This involves choosing a particular semantic frame to name (refer to) and talk about a particular situation (a categorization mechanism); the entailments of the frame (as inferences that can be drawn from it) will provide premises in the deliberation process;

3. Choosing a particular definition, often with an in-built bias or spin (i. e. a persuasive or rhetorically biased definition). The positive or negative bias contained in the definiens, which may be reasonable or not, might influence the audience one way or another.

4. Choosing a particular metaphor, comparison or analogy. Through their entailments, these too will provide premises in support of one conclusion or another.

5. Choosing a particular explanation: depending on which explanans is selectively made more salient, as a cause for current problems, or as a cause for potential consequences, a particular solution will be favoured in the conclusion.

6. Choosing particular narrative roles for the actors involved in the situation being framed: if the supporter of a project is cast in the "villain" role, then the audience will be invited to reject the proposal; an argument from analogy (the situation should be treated identically to another known situation, one in which the "villains" are not to be trusted) will therefore support the statement that there is a decisive objection against the proposal.

The main claim being made here is that all of these strategies are used within an argumentative, deliberative process, and they all involve a "selection and salience" mechanism, designed to help the audience reach a particular, desired deliberative outcome. What is 
being made salient, and potentially overriding, is a particular premise in an argument scheme that (directly or indirectly) supports or rebuts the proposal. This premise can belong to one of the main argument schemes involved in deliberation (e. g. alternative consequences, alternative values, alternative representations of "problems"), as shown in strategy 1 ; it can belong to a secondary argument scheme, subordinated to a main scheme, (e. g. a metaphorical re-description of the negative consequences, in argumentation from analogy, supporting the premise asserting their unacceptability in the main argument from negative consequence (strategies 2-4); finally, narratives, explanations or other non-argumentative macro-speech acts can provide premises for arguments that (directly or indirectly) support or rebut the proposal (strategies 5-6). We will illustrate each of these in turn:

\section{1) Making a main premise of the deliberative process selectively more salient and overriding}

As we have already seen, the two obligatory argument schemes potentially constituting a deliberation process are: an argument from goals in favour of a proposal, and an argument from negative consequence designed to critically test that proposal. Other nonobligatory schemes may also (independently, directly) support the proposal, e. g. arguments from positive consequence or from expert authority. Any of these premises, that directly support the proposal or its opposite, can be made selectively more salient. The campaign in favour of the project ${ }^{8}$ tended to emphasize the company's intended desirable goals (among which the alleged benefits to the Romanian state and the local area), as well as particular local circumstances (poverty, underdevelopment, people's right to work). In general, the benefits were said to outweigh the costs, and the impact on the environment and cultural heritage was presented as minimal, with emphasis on the reddressive action allegedly in place. Thus, the argument went, given the significant economic benefits to all parties

8 We refer here to the presentation of the project on RMGC's official website: RMGC: Roșia Montană Gold Corporation - Proiectul Roșia Montană (n. d.), not to RMGC advertising or other NGO-led campaigns in favour of the project. 
concerned, particularly the Romanian side, and given that these would clearly outweigh any negative impact (i. e. there would be no decisive objections), and also given the population's right to work (a deontic reason, in principle non-overridable), the Roșia Montană project ought to go ahead (see also Mădroane, 2014). Framing the deliberative process in this way, i. e. making these particular premises salient and potentially overriding, was intended to support a decision in favour of the project.

Arguments against the project ${ }^{9}$ emphasized primarily a range of unacceptable negative consequences: the potential destruction of four mountains and large forest areas, the environmental and health impact of the cyanide-based technology, the definitive loss of a precious mineral resource that Romania ought to be able to exploit in her own interest. These were presented as negative consequences that cannot be overridden by any benefits, particularly as job creation would be minimal, mainly sourced from outside the area, and for a limited period of time. The argument was also sometimes framed as an issue of inter-generational justice (it is Romania's duty towards future generations to keep the gold in the country for future exploitation) and predominantly as a legal issue (the unacceptability of infringing laws and violating property rights, the "unconstitutional" status of the 2013 draft law), thus making salient various sources of normativity involved. Framing the conflict in terms of unacceptable and non-overridable negative consequences (risks and impacts) was clearly intended to sway the deliberative process against the project, by providing decisive objections against it. ${ }^{10}$

The framing of the conflict developed over time, and new premises were made salient in the attempt to influence public opinion. Starting as a battle over the environment, the conflict developed into a battle over democracy and the rule of law in Romania,

9 For example, on the Alburnus Maior Association's website: rosiamontana.org - Campania Salvaţi Roșia Montană (n. d.).

10 Romanian citizens and NGO representatives who took part in public consultations on the Environmental Impact Assessment (EIA) Report submitted by the corporation in 2011 had emphasized the unacceptable consequences of the proposal on similar grounds (Mădroane, 2014). 
against "the privatisation of natural resources", in the context of a perceived "neoliberal consensus in post-socialist politics" and a "neo-colonialism" that gave precedence to the interests of global corporations over the interests of national states (Vesalon \& Creţan, 2013, p. 449; see also Chiper, 2012 and Velicu, 2012, 2014, 2015, for the protesters' opposition to neoliberal ideology). Reporting on the situation in Romanian in September 2013, an article in The Guardian (Ciobanu, 2013) cited an NGO activist as saying the following:

It is very interesting that such a revolt began with a case of protecting the environment, but this is not only about the environment [...] The Roșia Montană case -in which you see legislation custom made to serve the interests of a corporation- highlights some failures of both democratic institutions and of the economic system, capitalism in a broader sense [...] Roșia Montană is the battle of the present and of the next decades [...] It illustrates the end of post-1989 cleavages [communist vs. anti-communist, European vs. non-European] and the emergence of new ones. People today confront a corrupted political class backed up by a corporation and a soldout media; and they ask for an improved democratic process, for adding a participatory democracy dimension to traditional democratic mechanisms (cited in Ciobanu, 2013, par. 19-21).

In 2013, therefore, the conflict was no longer only about the environment, but about how global corporations can buy out national governments and national media, and force them to act in their interests, as well as about the population's demand for a truly representative democracy, as illustrated by the campaign slogan "Not in my name" ("Nu în numele meu"). The unacceptability of bending legislation so as to facilitate handing over Romania's resources to a multinational corporation was reflected in the slogan: "A corporation cannot dictate legislation" ("Nu corporaţia face legislaţia"), summing up the perceived worldwide subordination of states to corporate interests. This is what Monbiot (2001) theorized as the "captive state" or the "corporate takeover" of states, a phenomenon that threatens the very foundations of democratic government and undermines national sovereignty. The unacceptability of such violations of national law and sovereignty, made salient in the public interventions of the project's opponents and by the protesters, was likely to resonate with a wide audience, given widespread consensus about institutionalized corruption in Romania. 
In all of these cases, what was being made selectively more salient was one of the premises of the two main argument schemes involved in deliberative activity types, that are both necessary and together sufficient for rational decision-making (Fairclough, 2019a, 2019b): an argument from goals (including circumstances, normative sources, or "values", and means-goal relations) and an argument from consequence.

Examples 2-4 below illustrate the second mechanism we described above, where framing occurs in the premises of some secondary argument scheme which supports (and is subordinated to) the premises of the main argument schemes. This can be an argument from analogy, from definition, from classification, or any other argument which supports the proposal (or its opposite) indirectly, via the mediation of the arguments from goals or consequence.

\section{2) Choosing the "right" frame to support the "right" conclusion}

Framing by categorization may steer the public towards or away from a particular practical conclusion, via the entailments of the frame being used. On the view proposed here, categorization works as a framing strategy by making salient a premise in an argument scheme from classification (Walton et al., 2008) and illustrates a 'seeing as' mechanism: a particular entity or phenomenon is 'seen as' a case of particular category or class, and is said to fall under a particular conceptual label.

As might be expected, the frames of RISK and CAUSE HARM (both included in Fillmore's Frame Net dictionary) were widely used in talking about the negative effects of the project on the environment and public health. We will illustrate here some of the less predictable, more original frames. A popular campaign slogan was "Halt the Great Robbery" ("Opriţi Marele Jaf"). If, therefore, what the government is doing can be described as theft or robbery, i. e. in terms of the CRIME frame, then those actions should be opposed, seeing as theft and robbery are illegal, immoral, wrong (entailments drawn from the CRIME frame). Also belonging to the CRIME frame was the extended discourse on endemic, structural corruption in Romania. 
The government's stance was also equated with a declaration of war, in publicity material saying "The Government and RMGC have declared war on us all" ("Guvernul şi RMGC ne-au declarat război") and "do not forget that Romania is now under siege" ("nu uitaţi că România e acum în stare de asediu"). In addition to this WAR frame, a COMMERCIAL TRANSACTION FRAME APPEARED often, e.g. in placards and slogans asserting that "My Romania is not for sale", ("România mea nu e de vânzare"). The consequences of approving the project were therefore implicitly said to be unacceptable because they amounted to the government selling the country to foreigners or declaring war on its citizens. Seeing the situation in terms of war or a commercial transaction, therefore, supported a conclusion against the project. ${ }^{11}$

We have mentioned that Gabriel Resources is currently using an investor state dispute settlement (ISDS) mechanism, part of a global private court system (standing above national legal systems), to claim 4,4 billion US dollars from Romania in losses of expected profit. In 2017, an application was made by the Romanian ministry of culture to Unesco to have Roșia Montană recognized as a World Heritage site. In July 2018, however, Unesco decided to postpone the listing of Roșia Montană among its World Heritage sites, as a result of a lastminute request made by the Romanian Government, which claimed that granting this status to the area would weaken Romania's defence in the ongoing international arbitrage. The opponents of Gabriel Resources claimed that, on the contrary, having the area listed as a Word Heritage site would have strengthened Romania's position in this lawsuit. While different potential outcomes were made salient by each party, the Romanian government's standpoint on the issue was described by former minister of culture Vlad Alexandrescu as a clear case of treason and betrayal of national interest ("the state, captured by a gang of villains, has abjectly betrayed Romania's interests"), and as one more "shameful" demonstration of the collusion between Romania's corrupt political class and the Canadian corporation (Sandru, 2018). The frame of BETRAYAL or TREASON had also been

11 From a different perspective, Morasso (2012) and Bigi \& Morasso (2012) are making a similar point about how frames provide implicit premises in argumentation. 
amply used during the 2013 campaign, in slogans calling corrupt politicians, including the president and the prime minister, traitors.

\section{3) Choosing the "right" definition to support the "right' conclusion}

A typical definition operates by specifying a superordinate genus and a set of differences (differentia) that distinguish an object from other objects in the same genus. The relationship is hierarchical and can be paraphrased as $x$ is a kind of $y$ (or if something is an $x$, it will be $a y$ ). Unlike lexical or theoretical definitions, persuasive definitions (Walton, 2007) are not neutral but have an in-built bias, which may or may not be rationally defensible. All over the world, environmental protesters' actions are often redefined as CRIME, thus shifting them from one genus to another. For example, the Roșia Montană movement saw the protesters branded as terrorists ("ecoterrorists") in the media (Goțiu, 2013, p. 191). The negative bias introduced by adding environmental protesters to other kinds of terrorists, therefore criminals, under the same genus labels (terrorism and crime) is obviously one way of discrediting the movement, with potentially serious practical consequences for the individuals concerned. On the other hand, the owners (and "strategic investors") of Gabriel Resources and RMGC, as "businessmen", were also called "thieves" and "crooks". Seeing "businessmen" in these negative terms recategorizes them under the genus "criminals", ranking them together with thieves, crooks, traitors, etc. A similar recategorization of politicians under the genus "criminal" was attempted in the humorous adaptation of a Romanian proverb, "An uncaught thief is an honest merchant" ("Hoțul neprins e negustor cinstit"). This was turned into: "An uncaught traitor is an honest president" ("Trădătorul neprins e preşedinte cinstit"), and the extension of the term "traitor" (itself a hyponym of "criminal") was enlarged to include Romania's president at the time (Traian Băsescu). What is a president, therefore? It is a particular kind of traitor/criminal (genus), one that has not been caught yet (differentia). (This new, rhetorically biased definition is the semantic correlate of the reclassification/ 
recategorization process whereby the Romanian president was reassigned from the class "politician" to the class "criminal").

\section{4) Choosing the "right" metaphor to support the "right' conclusion}

Metaphor has long been recognized as a particularly effective framing device (Lakoff \& Johnson, 1980; Lakoff, 1993, 2004, 2016). It was imaginatively used in this campaign, where politicians and businessmen were branded "thieves" (on campaign placards simply saying "Thieves" ["Hoţii"]), while the project proposal itself was called "The Great Robbery", as noted above. Metaphors have an argumentative function, because inferences (entailments) can be drawn from them, functioning as premises supporting various conclusions. These particular metaphors ("thieves", "robbery") fit into the argument from negative consequence, supporting the premise that the effects will be unacceptable. If the whole project mounts to theft or robbery, i. e. the attempt to appropriate someone else's property, then it is illegal (and also morally wrong); these decisive objections against it indicate that it should be abandoned.

While the government's actions were talked about in terms of war (discussed above), the protest itself was called a revolution, with placards saying: "Our generation's own revolution" ("Revoluţia generaţiei noastre") or "Europe's Green Revolution". Seeing the protest movement as revolution was intended to legitimize it, its aim being to replace a corrupt status quo (similarly to the 1989 anticommunist revolution). ${ }^{12}$ Another placard said: "Arab spring, Turkish summer, Romanian autumn", emphasizing the similarities between the protests and other anti-system movements in recent memory. The Guy Fawkes mask (used in the 2006 film V for Vendetta) was also seen on the streets, as it had been during the Occupy movement in other cities, only a year or two before. Making salient, via such metaphors or analogies, the anti-system, anti-establishment dimension of the Romanian 2013 protest was clearly intended to legitimize it as the

12 This particular slogan marked a symbolic extension of the argument, from an environmental issue to broader post-communist transition issues, and the emergence of what Soare and Tufiş (2020, p.13) call a form of "total mobilization". 
right course of action and to create frame resonance. Here, an argument from analogy (the protest is similar to other legitimate movements and should be treated similarly) provided independent support for the conclusion that opposing the corporation's project was the right course of action.

Various other metaphors stole the headlines on both sides. In September 2013, an environment minister argued in favour of the project by using the metaphor of Roșia Montană as an ecological timebomb ("o adevărată bombă ecologică”), where centuries of previous mining had allegedly left behind a very polluted environment, which would now benefit from the high standards of operation promised by RMGC (Zachmann, 2013). More often, however, the same metaphor was used to reject the project, by pointing out that the cyanide lake that would be left behind in perpetuity would be the real "ecological timebomb".

Categorization, definition and metaphor, all involving seeing something "as" something else, are not always easy to keep apart and often occur together. Talking about events and situations in terms of CRIME (as a categorization mechanism) can be accompanied by definitions and metaphors drawn from the same semantic domain. Metaphors that map the domain of business or politics onto the domain of crime may be accompanied by persuasive definitions that subsume politicians and businessmen under the superordinate genus of "criminals". To keep these apart, we suggest, as a rule-of-thumb, that categorization can be paraphrased as "this is (a case of) CRIME", while both metaphor and definition need two terms, e. g. "this PROJECT is similar to ROBBERY", or "this PROTEST is similar to a REVOLUTION" (in the case of metaphor); respectively, "a POLITICIAN is a kind of CRIMINAL", and "a PROTESTER is a kind of TERRORIST" (in the case of definition).

Framing processes have a mobilizing potential, which can be achieved through "frame resonance". In contexts of social protest (but also in other contexts), various premises are made salient in ways that seek to establish a common ground for collective action, by tapping into (and sometimes by constructing) a common repertoire of beliefs, attitudes and values held by the target public. Framing the protest as a revolution or war, and diagnosing the situation in terms of crime and treason resonated well with the Romanians' collective memory of the 1989 anti-communist revolution, and with 
the post-communist consensus that the country had been captured by a corrupt political class. These frames were already well known to the public, and had been used in various forms over more than 10 years of conflict involving Roșia Montană. Their resonance was thus probably increased by the fact that they had stood the test of time, as presumably accurate diagnoses of what was going on in Romania.

The third framing mechanism (below, examples 5 and 6) involves non-argumentative genres, e. g. explanation or narrative. A particular explanans might be made more salient than an alternative one, or the actors of a real-world scenario might be mapped in a particularly striking way onto a set of archetypal, wellknown narrative roles.

\section{5) Choosing the "correct" explanation: "real" solutions addressing "real" causes}

Explanation is also used as a framing device, usually with either individual or systemic explanations for situations being given selective salience, depending on which line of action is favoured. The answer to the questions: why is this happening, and who is to blame? may point to systemic responsibility (governments, corporations, environment) or to individual responsibility (Fairclough \& Fairclough, 2012, pp. 171-172). Most explanations in the campaign attributed responsibility and blame to the government, the corporation and their corrupt relationship. A newspaper article appearing during the campaign attributed extreme weather and devastating floods in Romania to the irresponsible way in which hundreds of thousands of hectares of forests had been cut down since 1990, by the Romanians themselves, and warned that the planned destruction of four mountains and their forests, required by the mining project, would have devastating effects for the area (Diaconu, 2013). One of the most interesting uses of explanation throughout the Roșia Montană campaign was to speculate on the reasons why so many Romanian politicians had supported the project over the years in the face of fierce public opposition, suggesting that this support was directly related to their own financial benefits, the bribes they had received and their complicity in the illegal set up of the company (Goțiu, 2013). 


\section{6) Telling the most effective story: narratives with shared moral meaning}

Perhaps the most striking example of narrative framing was in terms of a 'David-and-Goliath' story: a small local organization (or particular individual activists) as 'David' versus a gigantic Canadian/ multinational 'Goliath'. An advanced search for this combination of terms ${ }^{13}$ yields over 21000 hits in Romanian and international online sources on Roșia Montană up to 20 April 2020.

Let us illustrate narrative framing with a more extended example. An American blogger of Romanian origin, writing (as 'King of Romania', currently as 'Sam cel Roman') from the Romanian city of Cluj during the September 2013 protests, gave an ironic account of the events in terms similar to children's stories. This, he tells us, is the story of a Romanian baby boy (later to become the man behind the Canadian corporation Gabriel Resources, also known as the "Emperor of West African Resources" for his controversial mining operations in Africa) who grows up and has various formative adventures and quests, in Australia and elsewhere, before meeting his nemesis, the French-Swiss journalist and environmental campaigner Stephanie Roth. ${ }^{14}$ Eventually, Roth was to play a decisive role in the organization and financing of the "Save Roșia Montană" campaign, and would "disrupt" the peaceful "equilibrium" of a business career that seemed to be forever on an upward successful trend (see Propp, 1975 [1928]; Todorov, 1977, and Toolan, 2012, for narrative theory). The mock Bildungsroman being sketched here (which includes "villains", "heroes", "false heroes" and "helpers", in a never-ending quest for gold) gives unique insight into the corrupt history of the founder of Gabriel Resources and RMGC, also documented in other Romanian publications (most notably Goțiu, 2013, who traces the history of several "golden boys" of the worldwide mining industry). ${ }^{15}$

13 The terms were "Rosia Montana", David, Goliath or Goliat.

14 This blog post also mentions that Stephanie Roth was awarded the Goldman Environmental Prize (worth 125000 USD) in 2005 for her activity at Roșia Montană; she generously used the money to finance the opposition of local NGOs to the project. See also her Wikipedia page and Goțiu (2013, pp. 346-351).

15 Goțiu also traces the links between Frank Timiş, his Romanian beneficiaries in the world of politics and business, and the pre-communist Securitate (i. e. secret police) 
[...] It's quite an interesting tale. It begins way back in the Communist days, when [...] a baby boy named Vasile Timiș was born in a tiny village in Maramureș in 1963.

At some point when he was a teenager, he and his family managed to emigrate to Australia where he began calling himself Frank. He learned to speak English and developed a taste for fast, easy money. Frank got mixed up with the wrong kind of folks and was arrested for possession of a sizable quantity of heroin in the late 1980s.

Frank learned from his mistakes and soon realized that there was far more profit to be made in spending other people's money instead of taking personal risks. All you had to do to become rich was to convince people that you owned a (literal) gold mine.

Starting in Australia, that's exactly what he did. He and his partners would form a limited liability company, acquire mining rights on a piece of land, gin up some feasibility reports and leverage this into getting investors to fund operations. If gold was actually found, then everybody went home happy and made a profit. If little or no gold was found, Frank and his partners still walked away with a sizable chunk of the investors' money (King of Romania, 2013).

The story continues, with several similar dubious operations being described, which take the hero from Australia to the UK but also to Africa. There, he branches out into petroleum extraction and diamond mining, before hearing one day of the deserted gold mines in his own native Transylvania and deciding to set up a partnership with the Romanian government, using one of his companies, Gabriel Resources (located in Barbados, for tax-evasion purposes).

And all was well for RMGC until a stubborn Swiss woman named Stephanie Danielle Roth heard about what was going on.

As a journalist focusing on environmental and ecological issues, Stephanie Roth was working at the time in Sighişoara to oppose the proposed creation of Dracula Park, a vampire-themed amusement park (that never came to fruition) in 2002. She heard about what was going on at Roşia Montană and decided to investigate, a decision that changed her life.

She was so moved by the issue that she emigrated to Romania, living

structures. According to him, Frank Timiş entered the Roşia Montană business with zero investment and left it with a profit of 70 million dollars. Similar figures are cited for his partners in Gabriel Resources but also for various Romanian businessmen (Goțiu, 2013, p. 280). Recently, Frank Timiş was mentioned in a BBC investigation of corruption in the gas and oil sector in Senegal, involving the president's brother, and was also the object of a Panorama BBC programme, documenting his tax evasion in the UK (BBC News, 2019a, 2019b). 
and working in Roșia Montană full-time while writing regularly on the subject for an influential British magazine called The Ecologist. This helped to bring global attention to Roșia Montană for the first time and she and her supporters credit her work to influencing the World Bank not to invest in the RMGC project in 2003 [...] (King of Romania, 2013).

Narratives and explanations are non-argumentative genres (or macro speech acts): nevertheless, they are sources for constructing arguments that will either support the premises of the basic deliberation scheme or directly support one or another of the two possible practical conclusions. Narrative framing creates a moral story, assigning narrative roles to real-world participants and inviting the public to reason by analogy with archetypal story lines. On the view proposed here, explanation and narrative are embedded in a broader deliberative process (see Fairclough \& Fairclough, 2012, pp. 171-172), where the public is invited to accept a proposal if it is supported by the "positive heroes" and to reject it if it is supported by the "villains"; alternatively to accept a solution that addresses the "real" causes of the problem, and reject one that does not.

\section{Conclusion}

This article has tried to make a contribution to framing theory by suggesting that framing is a process of making salient, and thus potentially overriding, a particular premise in a deliberative process that the audience is supposed to engage in, so as to arrive at a decision about what they should believe and/or do. Based on how they evaluate a variety of reasons, which in turn may depend on which reasons have been made salient and which have been omitted, and on what importance or "weight" has been attached to them in the deliberative process, the audience is supposed to reach a particular conclusion. Framing effects may be stronger or weaker depending on how the framing process interacts with the audience's own beliefs and values, and on the audience's exposure to alternative arguments, as well as their ability to assess and weigh these arguments together in a deliberative process.

Figure 1 shows the premises of the arguments from goals and from consequence that can be selected and made salient, in the attempt 
to direct the conclusion of this particular debate in a preferred way: the circumstances of action, for example the institutional constraints (laws, moral norms) or the problems that need solving; the (intended and unintended) consequences; the normative sources underlying action (obligations, rights, concern for public health and the environment), and so on. Figure 2 shows how premises intended to support those of the main arguments (from goals or consequence), for example, premises containing metaphors or persuasive definitions, can themselves be made salient, and how their entailments (the logical inferences that can be drawn from them) will be transferred upwards towards particular conclusions (e. g. if the project amounts to "robbery", then it is illegal; if it is illegal, then there is a decisive objection against it and it should be abandoned).

Taking for granted Entman's (1993) definition in terms of "selection and salience", as one of the most valuable insights of framing theory, we have defended an argumentative conception of how framing works. We have suggested that framing always involves the selective salience of some premise or other, in various argument schemes used in a deliberative process. Deliberating with oneself or with others, agents put forward proposals in light of desirable goals and values, and in light of their presumed potential to solve problems in particular contexts. Arguing from desirable goals, however, is never sufficient to establish that a course of action is the right one, even if the action can achieve those goals. Rational decision-making must involve, in addition to an argument from goals, a process of critical testing of proposals by thinking of their potential undesirable consequences, i. e. thinking of what objections would count against them. It is only when, in addition to hopefully achieving desirable goals, the proposal survives critical testing, in the sense that no decisive objections can be found against it, that it can be provisionally adopted as a reasonable course of action (and, as the case may be, a better alternative than other reasonable alternatives).

We have outlined three interrelated mechanisms, involving: (1) the selective salience of a particular premise of the arguments from goals and from consequence in the basic deliberation scheme; (2) the selective salience of a premise in a subordinate, secondary argument scheme (e. g. argument from analogy, definition or classification), 
supporting a premise belonging to the arguments from goals or consequence; (3) the selective salience given to some element of a non-argumentative macro speech act (explanation or narrative), in order to support a preferred conclusion. In the case of explanation, audiences may be invited to reason from some salient stated cause of a problem (as an alleged "fact" of the matter) to a particular conclusion for action; in the case of narrative, they may be invited to reason by analogy with a situation in which the "right" decision or course of action is clear and agreed upon, such as an archetypal story line. Finally, we have emphasized the importance of "resonance" between these salient premises and the public's beliefs, attitudes and values, as a crucial element in achieving a move to action $\mathbf{C}$

\section{Acknowledgment}

The authors gratefully acknowledge the support of COST Action CA17132 "European Network for Argumentation and Public Policy Analysis" ([http://www.publicpolicyargument.eu)] www. publicpolicyargument.eu), coordinated by Dr. Marcin Lewinski (New University Lisbon).

\section{References}

Aakhus, M. \& Lewiński, M. (2017). Advancing polylogical analysis of largescale argumentation: Disagreement management in the fracking controversy. Argumentation, 31(1), 179-207. https:/doi. org/10.1007s10503-016-9403-9

BBC News (2019a, June 3). The wealthy businessman who paid just $£ 35.20$ in tax. At: https://www.bbc.co.uk/news/business-48481320 (last accessed October 25, 2019).

BBC News (2019b, June 25). Alliou Sal, Senegal president's brother, resigns post amid corruption claim. At: https://www.bbc.com/news/worldafrica-48753099 (last accessed October 25, 2019).

Beciu, C., Ciocea, M. Mădroane, I.-D. \& Cârlan, A. I. (Eds.). (2018). Debating Migration as a Public Problem: National Publics and Transnational Fields. Peter Lang. 
Benford, R. D., \& Snow, D. A. (2000). Framing processes and social movements: An overview and assessment. Annual Review of Sociology, 26, 611-639. https://doi.org/10.1146/annurev.soc.26.1.611

Bigi, S. \& Morasso, S. G. (2012). Keywords, frames and the reconstruction of material starting points in argumentation. Journal of Pragmatics, 44(10), 1135-1149. https://doi.org/10.1016/j.pragma.2012.04.011

Cârlan, A. I., \& Ciocea, M. (2014). Media deliberation on intra-EU migration. A qualitative approach to framing based on rhetorical analysis. Romanian Journal of Communication and Public Relations, 16(3), 73-87. https://doi.org/10.21018/rjcpr.2014.3.177

Cârlan, A. I. \& Ciocea, M. (2018). Media deliberation on intra-EU migration. A qualitative approach to framing based on rhetorical analysis. In C. Beciu, M. Ciocea, I. D. Mădroane \& A. I. Cârlan (Eds.), Debating Migration as a Public Problem: National Publics and Transnational Fields (pp. 115-137). Peter Lang.

Chiper, S. (2012). Roșia Montană and its publics: governance and participatory democracy at community and corporate level. Argumentum: Journal of the Seminar of Discursive Logic, Argumentation Theory and Rhetoric, 10(1), 82-105. https://bit.ly/3f3TiVy

Chong, D. \& Druckman, J. N. (2007). Framing theory. Annual Review of Political Science, 10, 103-127. https://doi.org/10.1146/annurev. polisci.10.072805.103054

Ciobanu, C. (2013, September 17). Romanians mobilise in protest against gold mine plans. The Guardian. https://bit.ly/3d2C48X

D’Angelo, P. \& Kuypers, J. A. (Eds.). (2010). Doing News Framing Analysis. Empirical and Theoretical Perspectives. Routledge.

Diaconu, B. (2013, September 13). Urgia apelor nu vine din cer, ci de pe pământ. Adevărul. https://bit.ly/2zBiTEU

Egresi, I. (2011). The curse of the gold: discourses surrounding the project of the largest pit-mine in Europe. Journal of Studies and Research in Human Geography, 5(2), 57-68. https://doi.org/10.5719/hgeo.2011.52.57

Entman, R. M. (1993). Framing: Toward clarification of a fractured paradigm. Journal of Communication, 43(4), 51-58. https://doi. org/10.1111/j.1460-2466.1993.tb01304.x 
Fairclough, I. (2016). Evaluating policy as practical argumentation and deliberation: the public debate over the first UK Austerity Budget. Critical Discourse Studies, 13(1), 57-77. https://doi.org/10.1080/1740590 4.2015.1074595

Fairclough, I. (2018). "Conductive" Argumentation in the UK Fracking Debate. In: Oswald, S. \& Maillat, D. (Eds.), Argumentation and Inference: Proceedings of the 2nd European Conference on Argumentation, vol. 2 (pp. 299-312). College Publications.

Fairclough, I. (2019a). Deontic power and institutional contexts: The impact of institutional design on deliberation and decision-making in the UK fracking debate. Journal of Argumentation in Context, 8(1), 138-173. http://clok.uclan.ac.uk/21846/

Fairclough, I. (2019b). Is there such a thing as a "conductive argument"? Pro/con argumentation in the temporal unfolding of a deliberative process. In B. Garssen, D. Godden, G. R. Mitchell, J. Wagemans (Eds.), Proceedings of the Ninth Conference of the International Society for the Study of Argumentation (pp. 342-351). SicSat. https://bit.ly/3bPEtUi

Fairclough, I. (2019c). Is 'conductive' argument a single argument? In F. H. Van Eemeren, \& B. Garssen, (Eds.), From argument schemes to argumentative relations in the wild. A variety of contributions to argumentation theory (pp. 223-238). Springer.

Fairclough, I. \& Fairclough, N. (2011). Practical reasoning in political discourse: the UK government's response to the economic crisis in the 2008 Pre-Budget Report. Discourse EO Society, 22(3), 243-268. https://doi.org/10.1177/0957926510395439

Fairclough, I. \& Fairclough, N. (2012). Political Discourse Analysis: A Method for Advanced Students. Routledge.

Fairclough, I. \& Fairclough, N. (2013). Argument, deliberation, dialectic and the nature of the political: A CDA perspective. Political Studies Review, 11(3), 336-344. https://doi.org/10.1111/1478-9302.12025

Fairclough, I. \& Mădroane, I. D. (2014). An argumentative approach to policy "framing". Competing "frames" and policy conflict in the Roşia Montană case. In B. Garssen, D. Godden, G. Mitchell, \& A. F. Snoeck Henkemans (Eds.), Proceedings of the 8th International Conference of the International Society for the Study of Argumentation. SicSat. 
Fillmore, C. J. (1985). Frames and the semantics of understanding. Quaderni di Semantica, 6(2), 222-254. https://bit.ly/35ge67x

Fillmore, C. J. (2006). Frame semantics. In E. K. Brown (Ed.), Encyclopaedia of Language and Linguistics, vol. 4 (pp. 613-620). Elsevier.

Fillmore, C. J. \& Atkins, B. T. (1992). Toward a frame-based lexicon: The semantics of risk and its neighbours. In A. Lehrer, \& E. F. Kittay (Eds.), Frames, Fields, and Contrasts: New Essays in Semantic and Lexical Organization (pp. 75-102). Erlbaum.

Gabriel Resources (2015). The Roșia Montană Gold Ë Silver Project: A Project for Romania. Roșia Montană Website, Investors Presentations [BMO Capital Markets 23 ${ }^{\text {rd }}$ Global Metals \& Mining Conference]. https://bit.ly/2y2qXhM

Gamson, W. A. (1995). Constructing social protest. In H. Johnston, \& B. Klandersmans (Eds.), Social Movements and Culture 4 (pp. 85-106). University of Minnesota Press.

Gamson, W. A. (2013). Injustice frames. In D. A. Snow, D. della Porta, B. Klandermans, \& D. McAdam (Eds.), The Wiley-Blackwell Encyclopaedia of Social and Political Movements (pp. 607-608). Willey-Blackwell.

Gitlin, T. (1980). The Whole World Is Watching: Mass Media in the Making and Unmaking of the New Left. University of California Press.

Gold Corporation Roşia Montană (n. d.). Campania Salvaţi Roșia Montană. https://www.rmgc.ro/

Goțiu, M. (2013). Afacerea Roșia Montană. TACT.

International Computer Science Institute at Berkeley, California (n. d.). FrameNet Project. https://framenet.icsi.berkeley.edu/fndrupal/

King of Romania [blog] (2013). The complete and true story of Roșia Montană. At: HYPERLINK https://kingofromania.com/2013/09/16/ the-complete-and-true-story-of-Roșia-Montană/ (last accessed October 23, 2019).

Lakoff, G. (1993). The contemporary theory of metaphor. In A. Ortony (Ed), Metaphor and Thought, 2. ${ }^{\text {a }}$ ed. (pp. 202-251). Cambridge University Press. 
Lakoff, G. (2004). Don't think of an elephant! Know your values and frame the debate. Chelsea Green Publishing.

Lakoff, G. (2016). Moral Politics: How Liberals and Conservatives Think (3. ed.). University of Chicago Press.

Lakoff, G., \& Johnson, M. (1980). Metaphors We Live By. University of Chicago Press.

Lewiński, M. (2016). Shale gas debate in Europe: Pro-and-con dialectics and argumentative polylogues. Discourse $\mathcal{B}$ Communication, 10(6), 553-575. https://doi.org/10.1177/1750481316674773

Mădroane, I. D. (2014). Citizens' consultations - public spaces of argument evaluation? A view from critical discourse analysis. Romanian Journal of English Studies, 11(1), 203-214. https://doi.org/10.2478/rjes-2014-0024

Mădroane, I. D. (2016). Metaphors and calls for action in media advocacy campaigns on social issues. In L. Pungă (Ed.), Language in Use: Metaphors in Non-Literary Contexts (pp. 169-191). Cambridge Scholars Publishing.

Mădroane, I. D. (2018). Migrant identities and practices in media advocacy campaigns: The construction of claims and audiences. In C. Beciu, M. Ciocea, I. D. Mădroane, \& A. I. Cârlan (Eds.), Debating Migration as a Public Problem: National Publics and Transnational Fields (pp. 175198). Peter Lang.

Mădroane, I. D. (2019). Television dispositives and the enactment of advocacy arguments. In F. H. van Eemeren \& B. Garssen (Eds.), Argumentation in Actual Practice: Topical studies about argumentative discourse in context, vol. 17 (pp. 33-59). John Benjamins.

Miller, D. W. (1994). Critical rationalism: A restatement and defence. Open Court.

Miller, D. W. (2006). Out of error. Further essays on critical rationalism. Routledge.

Monbiot, G. (2001). Captive State. The Corporate Takeover of Britain. Pan Books.

Morasso, S. G. (2012). Contextual frames and their argumentative implications: a case-study in media argumentation. Discourse Studies, 14(2), 197-216. https://doi.org/10.1177/1461445611433636 
Nelson, T. E., Clawson, R. A., Oxley, Z. M. (1997). Media framing of a civil liberties conflict and its effect on tolerance. The American Political Science Review, 91(3), 567-583. https://doi.org/10.2307/2952075

Nisbet, M. C. (2010). Knowledge into action: Framing the debates over climate change and poverty. In P. D'Angelo \& J. A. Kuypers (Eds.), Doing News Framing Analysis (pp. 43-83). Routledge.

Noakes, J. A., \& Johnston, H. (2005). Frames of protest: A road map to a perspective. In H. Johnston \& J. A. Noakes (Eds.), Frames of Protest: Social Movements and the Framing Perspective (pp. 1-29). Rowman \& Littlefield Publishers.

Plăiaș, I. (2012). Reflection upon the usefulness of the Roșia Montană project. In P. Cocean (Ed.), Roșia Montană in Universal History (pp. 58-67) [Romanian Academy, Babeș-Bolyai University, icomos Romania]. Cluj University Press.

Proiectul Roșia Montană/ Roșia Montană Project (n. d.). RMGC: Roșia Montană Gold Corporation - Proiectul Roșia Montană [Roșia Montană Gold Corporation Website]. https://bit.ly/3f1cj14

Propp, V. (1975 [1928]). The Morphology of the Folk Tale. University of Texas Press.

Reese, S. D. (2001). Framing public life: A bridging model for media research. In S. D. Reese, O. H. Gandy \& A. E. Grant (Eds.), Framing Public Life: Perspectives on Media and Our Understanding of the Social World (pp. 7-31). Erlbaum.

Sandru, A. (2018, July 2). Vlad Alexandrescu, despre situația Roşiei Montane: Statul, acaparat de o gașcă de ticăloși, a trădat mișelește interesele Romaniei. Ziare.com. https://bit.ly/3bJtYlw

Schön, D. A. (1993). Generative metaphor: a perspective on problemsetting in social policy. In A. Ortony (Ed), Metaphor and Thought, 2.a ed. (pp. 137-163). Cambridge University Press.

Searle, J. R. (2010). Making the Social World. The Structure of Human Civilization. Oxford University Press.

Sniderman, P. M., \& Theriault, S. M. (2004). The Structure of political argument and the logic of issue framing. In P. M. Sniderman, \& W. E. Saris (Eds.), Studies in Public Opinion: Attitudes, Nonattitudes, Measurements, Error and Change (pp. 133-155). Princeton University Press. 
Soare, S. \& Tufiș, C. D. (2020). 'Roșia Montană, the revolution of our generation': from environmental to total activism. European Politics and Society, 1-18. https://doi.org/10.1080/23745118.2020.1729052

Todorov, T. (1977). The Poetics of Prose. Blackwell.

Toolan, M. (2012). Narrative: A Critical Linguistic Introduction (2. a ed.). Routledge.

Van Eemeren, F. H. (2010). Strategic Maneuvering in Argumentative Discourse. John Benjamins.

Van Eemeren, F. H., \& Grootendorst, R. (2004). A Systematic Theory of Argumentation. The Pragma-Dialectical Approach. Cambridge University Press.

Velicu, I. (2012). To sell or not to sell: landscapes of resistance to neoliberal globalization in Transylvania. Globalizations, 9(2), 307-321. https://doi. org/10.1080/14747731.2012.658253

Velicu, I. (2014). Moral versus commercial economies: Transylvanian stories. New Political Science, 36(2), 219-237. https://doi.org/10.1080/0 7393148.2014.883804

Velicu, I. (2015). Demonizing the sensible and the 'Revolution of our generation' in Roșia Montană. Globalizations, 12(6), 846-858. https:// doi.org/10.1080/14747731.2015.1100858

Vesalon, L., \& Creţan, R. (2013). 'Cyanide kills!' Environmental movements and the construction of environmental risk at Roșia Montană, Romania. AREA, 45(4), 443-451. https://doi.org/10.1111/area.12049

Walton, D. (2006). Fundamentals of Critical Argumentation. Cambridge University Press.

Walton, D. (2007). Media Argumentation. Cambridge University Press.

Walton, D., Reed, C. \& Macagno, F. (2008). Argumentation Schemes. Cambridge University Press.

Zachmann, S. (2013, September 10). Rovana Plumb: "În prezent, la Roșia Montană este o adevărată bombă ecologică". Adevărul. https://bit. ly/3dau $71 \mathrm{~V}$ 